\title{
An integrated mathematical model for the milk collection problem
}

\section{Süt toplama problemi için bütünleșik bir matematiksel model}

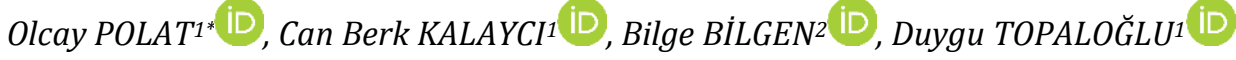 \\ 1Department of Industrial Engineering, Engineering Faculty, Pamukkale University, Denizli, Turkey. \\ opolat@pau.edu.tr, cbkalayci@pau.edu.tr, duygutopaloglu91@gmail.com \\ 2Department of Industrial Engineering, Engineering Faculty, Dokuz Eylul University, İzmir, Turkey. \\ bilge.bilgen@deu.edu.tr
}

Received/Geliș Tarihi: 12.06.2019, Accepted/Kabul Tarihi: 02.12.2019

* Corresponding author/Yazışılan Yazar

\section{Abstract}

The number of microorganisms and chemical values of the milks separated according to their quality are different from each other. In case of mixing different quality types of milk, composed milk quality is considered equal to the lowest quality milk type among the types of milk added to the mixture. Therefore, different types of raw milk should not be mixed during collection. The problem of milk collection is related to the collection of raw milk, which is separated according to the quality types, from the producers at different points by multi-tank tankers. In this study, an integrated mathematical model has been developed to collect different quality types of raw milk at different points under the specified time limit by means of tankers having multiple tanks. The results obtained by solving a hypothetical case study with ILOG CPLEX show that proposed model allows to optimally collect different type of raw milks without mixing. Thus, it will be possible to produce higher quality dairy products.

Keywords: Milk collection problem, Vehicle routing problem, Mathematical model, Logistics

\section{Introduction}

Milk which has a very significant role in everyday nourishment can be very harmful to human health unless produced, stored, collected and processed in hygienic conditions.

Milk collection problem (MCP) is basically concerned with the collection of raw milk with different qualities at dairy factories via tankers under problem specific constraints. During this process, collection of milk in different qualities without mixing is at least as critically important as product quality. Because final milk quality is accepted to be equal to the quality of the milk with the worst quality when the milk of different qualities is mixed.

In the literature, the milk collection problem is generally shown in location routing problems (LRP), rich vehicle routing problems (RVRP), and truck and trailer routing problems (TTRP). An interested reader is referred to the review articles [1]-[3] on LRP, VRP, RVRP, and TTRP, respectively.

It is seen that most of the studies in MCP literature deal with the problem through vehicle routing constraints, other constraints inherent in the problem are neglected [4]-[6]. The studies within this framework, have either reduced the problem to subproblems (assignment or routing) or solved the problem sequentially (first assignment, then routing). On the other hand, some of the studies on milk collection problem in the literature have taken into consideration vehicle routing constraints as well as location requirement constraints. doi: $10.5505 /$ pajes.2019.06791

Special Issue Article/Özel Sayı Makalesi

\section{Öz}

Kalitelerine göre ayrılmış sütlerin içerikleri mikroorganizma sayısı, kimyasal değerleri birbirinden farklıdır. Farklı kaliteye sahip sütlerin karıştırılması durumunda oluşan sütün kalitesi, karışıma katılan sütler arasındaki en düșük kaliteye sahip olan süt tipinin kalitesine eșit kabul edilmektedir. $B u$ yüzden fakl kalitedeki sütler toplanırken karıștırılmamalıdır. Süt toplama problemi farklı noktalarda bulunan üreticilerden, kalite tiplerine göre ayrılmıs çiğ sütlerin, çok tanka sahip tankerler aracılığı ile toplanması ile ilgilenmektedir. Bu çalışmada; farklı noktalarda bulunan farklı kalitede ki çiğ sütlerin, çok tanka sahip tankerler aracllı̆̆ ile belirlenen zaman limiti altında toplanmasını sağlayacak bütünleșik bir matematiksel model olusturulmustur. Varsayımsal bir vaka çalıșmasının ILOG CPLEX ile çözülmesi ile elde edilen sonuçlar göstermektedir ki önerilen model farklı kalitedeki çiğ süt tiplerinin karıstırılmadan en etkin sekilde toplanmasına izin vermektedir. Böylece daha yüksek kalitede süt ürünleri üretilmesi mümkün olabilecektir.

Anahtar kelimeler: Süt toplama problemi, Araç rotalama problemi, Matematiksel model, Lojistik
Hoff and Løkketangen [7] studied real-life milk collection problem for only one milk type as a truck trailer routing problem and developed a Tabu search algorithm to solve the problem. The authors used heterogenous one compartment vehicle fleet and geographical conditions of farms which restrict accessibility of locations by different vehicles. Pasha et al. [8] solved MCP by using a hybrid solution approach which includes the Merging and Splitting Technique (MST) in the Tabu search algorithm. Amiama et al [9], developed a spatial decision support system (SDSS) to solve the milk collection problem in two stages. First, the heuristic system produced a solution then the graphic system improved the solution by allowing the changes in the route. SDSS is a useful tool for the operator to see the results of different scenarios, however, the algorithm did not contain optimization tool for routes.

Chokanat et al. [10] modified Differential Evolution algorithm (DE) to solve the MCP. The authors used multi compartment vehicle fleet in their study and allowed two different types of farm milk to be loaded into one compartment. However, in reallife cases, one supplier may have different types of milk and compartments can contain more milk than farms.

Montero et al. [11], tackled a real-world case for a milk processing company located in the south of Chile and solved this problem both as a Prize-Collecting Vehicle Routing Problem (PCVRP) and as Greedy Randomized Adaptive Search Process (GRASP) approach. Their model aims to collect enough milk to meet the dairy company's milk demand at minimum 
cost, so it is not necessary to visit all suppliers, however, they did not consider the difference in the milk type. Polat and Topaloğlu [12] proposed a fuzzy mathematical model to meet the probabilistic nature of the milk collection problem. They designed the model to collect the milk from suppliers by splitting it with multi-compartment vehicles. Nevertheless, they designed this model without considering different type of milks.

In the study conducted by Caramia and Guerriero [13], the requirement to collect different milk types without mixing was also taken into consideration. However, they solved the problem sequentially in two stages. In the first step, they solved the problem as a tanker assignment problem, in the second step they solved the problem as a vehicle routing problem. In their method, considered the problem-specific constraints, more practical solutions have been obtained. However, the quality of the solution has been decreased due to the sequentially solving method.

In this study, in addition to vehicle routing constraints, some important constraints specific to milk collection problem were also considered. These specific constraints are milk types constraint, service duration time limit constraints, multi tank constraints and divisible demand constraints. In this study, an integrated mathematical model that provides a multi-product multi-compartment vehicle routing problem with split deliveries has been developed for the first time in the literature. The remaining parts of this paper structured as follows: section 2 describes an integrated mathematical model; section 3 presents a hypothetical case study to illustrate the model's performance; Section 4 designed for specified the mathematical model's limit; Section 5 illustrated the sensitivity analyses and ANOVA analysis; finally, section 6 shows the conclusion of this study and directions for future research.

\section{Mathematical model}

This problem is modelled as a multi-compartment vehicle routing problem with split deliveries (MC-VRP-SD). Mathematical model assumptions for this problem are;

- All different types of milk produced by each farm/milk collection center should be gathered due to supplier agreement,

- $\quad$ Raw milk types categorized by an expert and it is ready for collection under ideal temperature conditions,

- Farms/Collection center may provide each type of milk,

- Different types of milk cannot get blended,

- Mixing of the same type of raw milk collected from different producers is allowed,

- The collected amount of raw milk cannot exceed related tank capacities,

- Each tank may visit each farm/collection center one time,

- Each tank can visit each farm/collection center, but the number of visits must not be more than once,

- Each farm/collection center can be visited by each of different tanks,

- Each tank must start and end its route at the dairy factory,

- Raw milk collection must be completed within the specified time limit
- $\quad$ Service times are considered fixed. The split of the demand does not affect the service time.

The objective is to minimize the total distance travelled by the tankers in the network. MC-VRP-SD problem notations are;

\begin{tabular}{|c|c|}
\hline \multicolumn{2}{|l|}{ Indices } \\
\hline$i, j \in N$ & $\begin{array}{l}\text { set of nodes (0: dairy factory, } 1 . . \mathrm{N} \text { : } \\
\text { farms/collection centers) }\end{array}$ \\
\hline$k \in K$ & set of tanks \\
\hline$l \in L$ & set of tankers on a tank \\
\hline$m \in M$ & raw milk types in the collection area \\
\hline \multicolumn{2}{|c|}{ Parameters } \\
\hline$Q_{k l}$ & capacity of tanker $l$ on tank $k$ \\
\hline$C_{i j}$ & distance between node $i$ an $j$ \\
\hline$D_{i m}$ & $\begin{array}{l}\text { to be collected amount of type } m \text { raw milk } \\
\text { from farm/collection center } i\end{array}$ \\
\hline$S_{i}$ & service time at farm/collection center $i$ \\
\hline$V$ & average speed of tanks \\
\hline$T$ & $\begin{array}{l}\text { maximum route duration for delivering } \\
\text { collected raw milk to the dairy factory }\end{array}$ \\
\hline \multicolumn{2}{|c|}{ Decision variables } \\
\hline$x_{i j k}$ & $\begin{array}{l}\text { 1: if the arc between the node } i \text { and } j \text { is } \\
\text { served by tanker } k \text {; } 0 \text { : otherwise }\end{array}$ \\
\hline$z_{k}$ & $\begin{array}{c}1: \text { if the tank } k \text { is used in the network; } 0: \\
\text { otherwise }\end{array}$ \\
\hline$w_{k l m}$ & $\begin{array}{l}\text { 1: if the tanker } l \text { on the tank } k \text { is assigned } \\
\text { to the milk type } m ; 0: \text { otherwise }\end{array}$ \\
\hline$y_{i k}$ & 1 : if the tank $k$ visited node $i ; 0:$ otherwise \\
\hline$f_{i k}$ & $\begin{array}{l}\text { Fulfillment ratio for farm/collection } \\
\text { center } i \text { by using tank } k\end{array}$ \\
\hline
\end{tabular}

This mathematical model is designed as a Mixed Integer Linear Programming (MILP) model using the notations given above. The proposed model contains a multi-compartment vehicle routing problem with split deliveries (MC-VRP-SD) is here;

minimize $Z=\sum_{i \in N} \sum_{j \in N} \sum_{k \in k} C_{i j} x_{i j k}$

$\sum_{i \in N} \sum_{k \in K} x_{i j k} \geq 1$

$\forall j \in N /\{0\}$

$\sum_{j \in N /\{0\}} x_{0 j k} \leq 1$

$\forall k \in K$

$\sum_{i \in N /\{0\}} x_{i 0 k} \leq 1$

$\forall k \in K$

$\sum_{i \in N} \sum_{j \in N} x_{i j k} \leq|N| z_{k}$

$\forall k \in K$ 
$\sum_{i \in N} \sum_{j \in N} x_{i j k} \geq z_{k}$

$\forall k \in K$

$\sum_{m \in M} w_{k l m} \leq z_{k}$

$\forall k \in K, l \in L$

$f_{j k} \leq \sum_{i \in N} x_{i j k}$

$\forall j \in N / 0$,

$k \in K$

$\sum_{k \in K} f_{i k}=1$

$\forall i \in N /\{0\}$

$\sum_{i \in N /\{0\}} D_{i m} f_{j k} \leq \sum_{l \in L} Q_{k l} w_{k l m}$

$\forall k \in K$, $m \in M$

$\sum_{i \in N} \sum_{j \in N, i \neq j} \frac{a_{i j} x_{i j k}}{V}+\sum_{i \in N} S_{i} y_{i k} \leq T \quad \forall k \in K$

$\sum_{j \in N} x_{i j k}+\sum_{j \in N} x_{j i k}=2 y_{i k}$

$\forall i \in N, k \in K$

$\sum_{i \in Z} \sum_{j \in Z, i<j} x_{i j k} \leq \sum_{i \in Z} y_{i k}-y_{z k}$

$Z \subseteq N \backslash\{0\}$
$Z \in Z$
$k \in K$

$\sum_{i \in N} \sum_{k \in K} x_{i i k}=0$

$f_{i k} \geq 0$

$\forall i \in N, k \in K$

$$
x_{i j k}, y_{k}, w_{k l m}, z_{k} \in\{0,1\}
$$

Each farm/collection center's location, service duration time, product type and amount of this type given into Table 1 .

Table 1: Hypothetical case study data set.

\begin{tabular}{ccccccc}
\hline & \multicolumn{3}{c}{ Milk Type (L) } & \multicolumn{2}{c}{$\begin{array}{c}\text { Service } \\
\text { Duration }\end{array}$} & \multicolumn{2}{c}{ Location } \\
\cline { 2 - 7 } Client & \multirow{2}{*}{$\alpha$} & $\beta$ & $\gamma$ & $\begin{array}{c}\text { Time } \\
\text { (min) }\end{array}$ & $\mathrm{X}$ & $\mathrm{Y}$ \\
\hline 1 & 0 & 0 & 0 & 1 & 0 & 0 \\
2 & 2000 & 2000 & 0 & 15 & 975.690 & 411.985 \\
3 & 0 & 0 & 5500 & 20 & 457.692 & 977.378 \\
4 & 45 & 200 & 0 & 15 & 336.499 & 148.107 \\
5 & 35 & 0 & 0 & 25 & 867.212 & 241.269 \\
6 & 50 & 500 & 0 & 25 & 919.882 & 547.194 \\
7 & 0 & 0 & 500 & 10 & 766.775 & 360.531 \\
8 & 1000 & 1000 & 500 & 15 & 376.221 & 264.250 \\
9 & 200 & 500 & 500 & 25 & 998.429 & 979.084 \\
\hline
\end{tabular}

The dairy firm has four different types of tanks. There is only one tanker in a tank, there are three tankers in two tanks whose capacities are different, while in the last tank there are two tankers. Tanks and capacities of the tankers in these tanks are given in Hata! Yer işareti başvurusu geçersiz..

Table 2: Tank \& Tanker capacities.

\begin{tabular}{ccrc}
\hline \multirow{2}{*}{ Tanks } & \multicolumn{3}{c}{ Tankers (L) } \\
\cline { 2 - 4 } & 1 & 2 & 3 \\
\hline 1 & 5000 & & \\
2 & 5000 & 5000 & 5000 \\
3 & 2000 & 2000 & 2000 \\
4 & 4000 & 4000 & \\
\hline
\end{tabular}

Milk quality depends on different type of quality characteristics. The time limit is determined as 3000 minutes, for each tank`s total route duration. Each tank`s average speed taken as a $60 \mathrm{~km} / \mathrm{hour}$.

In the hypothetical case study, each farm/collection center has its own service time. The service time constraint is considered stationary, if the demand of the farm splited, the farm service time is not affected this situation. All experiments were conducted on a workstation with Intel Xeon $3.7 \mathrm{GHz}$ processor and $32 \mathrm{~GB}$ of RAM.

The hypothetical case study is solved in Gams 23.4.3 version by using CPLEX 12.1.0 solver. The solution is illustrated in Figure 1 as service network map and is shown in Table 3.

Table 3: Conclusion of the hypothetical case study. Constraint (10) guarantees that the amount of raw milks assigned to a tank cannot exceed related tanker's capacity. Constraint (11) represents the maximum duration limit for collected raw milks in a tank. Constraint (12) specifies the degree of each node while constraints (13) prohibits the formation of illegal subtours [14]. Constraints (14) aims to improve model performance. Constraints (15) defines the nature of the ratio variables. Constraints (16) defines the binary nature of the variables.

\section{Hypothetical case study}

A hypothetical case study test model based on real-life data was designed, for the measure of the model performance by using VRP instances [15],[16]. The hypothetical case study has 8 farm/collection center, 1 milk processing center. Each farm/collection center has at least one type of milk.

\begin{tabular}{ccccccccccccc} 
Tank & & & \multicolumn{4}{c}{ Route } & & & & $\begin{array}{c}\text { Route } \\
\text { Distance }(\mathrm{km})\end{array}$ & $\begin{array}{c}\text { Service } \\
\text { Duration } \\
\text { (min) }\end{array}$ \\
\hline 2 & 1 & 8 & 9 & 6 & 2 & 5 & 7 & 4 & 1 & 319.843 & 131 \\
3 & 1 & 3 & 1 & & & & & & & 215.848 & 21 \\
\hline & & & & & & & Total & 535.691 & 152 \\
\hline
\end{tabular}

The model was forced due to the 5500-liter milk supply in node 3 in the basic data set. The model solves the problem by assigning a single tank to this manufacturer, but the distribution of the milk to tankers is left to the user's preference. Therefore, in Table 4, capacity utilization rates for vehicle 3 could not be given. 
Table 4: Tank assignment of the hypothetical case study.

\begin{tabular}{ccccccc}
\hline & \multicolumn{3}{c}{ Assigned Milk Type } & \multicolumn{3}{c}{$\begin{array}{c}\text { Tanker Usage } \\
\text { (L/capacity) }\end{array}$} \\
\cline { 2 - 7 } Tank & Tanker & Tanker & Tanker & Tanker & Tanker & Tanker \\
& 1 & 2 & 3 & 1 & 2 & 3 \\
\hline 2 & $\beta$ & $\alpha$ & $\gamma$ & $84 \%$ & $67 \%$ & $30 \%$ \\
3 & $\gamma$ & $\gamma$ & $\gamma$ & $*$ & $*$ & $*$ \\
\hline
\end{tabular}

\section{Experimental design}

Experimental test sets were created to measure the response of the model to the increase in the number of nodes. The amount of milk production data of the experimental test sets is given in Table 5. Service times and location information are only added to the model for the newly added nodes. The service times and location information of the new nodes added are given in Table 6.
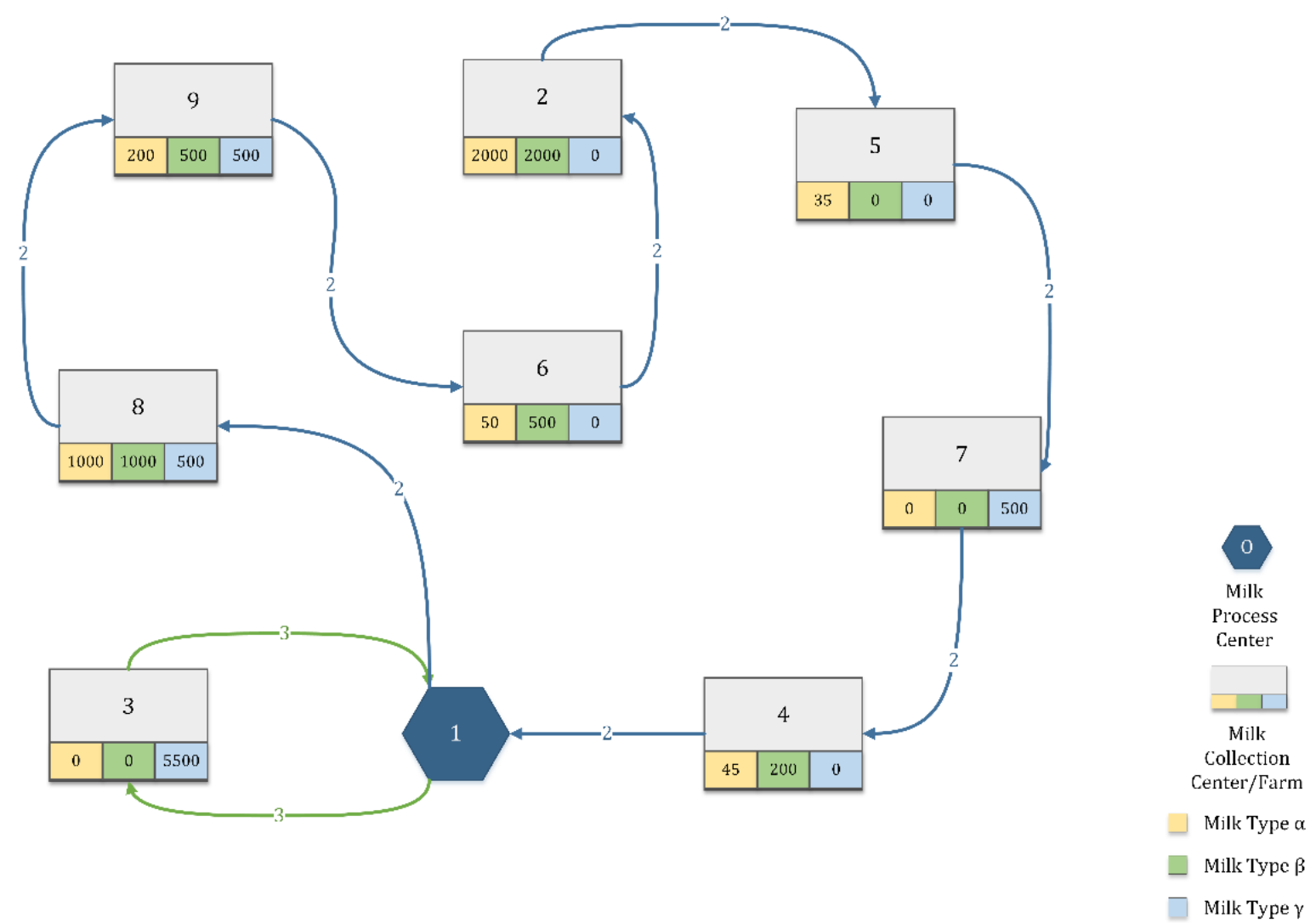

Figure 1: Service network map.

Table 5: Experimental test sets.

\begin{tabular}{|c|c|c|c|c|c|c|c|c|c|c|c|c|c|c|c|}
\hline & \multicolumn{3}{|c|}{ Base Test } & \multicolumn{3}{|c|}{ Test 1} & \multicolumn{3}{|c|}{ Test 2} & \multicolumn{3}{|c|}{ Test 3} & \multicolumn{3}{|c|}{ Test 4} \\
\hline \multirow{2}{*}{ Nodes } & \multicolumn{3}{|c|}{ Milk Production (L) } & \multicolumn{3}{|c|}{ Milk Production (L) } & \multicolumn{3}{|c|}{ Milk Production (L) } & \multicolumn{3}{|c|}{ Milk Production (L) } & \multicolumn{3}{|c|}{ Milk Production (L) } \\
\hline & $\alpha$ & ] & $\gamma$ & $\alpha$ & ? & $\gamma$ & $\alpha$ & ? & $\gamma$ & $\alpha$ & 圆 & $\gamma$ & $\alpha$ & ] & $\gamma$ \\
\hline 1 & 0 & 0 & 0 & 0 & 0 & 0 & 0 & 0 & 0 & 0 & 0 & 0 & 0 & 0 & 0 \\
\hline 2 & 2000 & 2000 & 0 & 2000 & 2000 & 0 & 2000 & 2000 & 0 & 100 & 4200 & 0 & 100 & 4200 & 0 \\
\hline 3 & 0 & 0 & 5500 & 0 & 0 & 5500 & 0 & 0 & 5500 & 0 & 0 & 500 & 0 & 0 & 500 \\
\hline 4 & 45 & 200 & 0 & 45 & 200 & 0 & 45 & 200 & 0 & 45 & 200 & 0 & 45 & 200 & 0 \\
\hline 5 & 35 & 0 & 0 & 35 & 0 & 0 & 35 & 0 & 0 & 35 & 0 & 0 & 35 & 0 & 0 \\
\hline 6 & 50 & 500 & 0 & 50 & 500 & 0 & 50 & 500 & 0 & 50 & 500 & 0 & 50 & 500 & 0 \\
\hline 7 & 0 & 0 & 500 & 0 & 0 & 500 & 0 & 0 & 500 & 0 & 0 & 500 & 0 & 0 & 500 \\
\hline 8 & 1000 & 1000 & 500 & 1000 & 1000 & 500 & 1000 & 1000 & 500 & 1000 & 1000 & 500 & 1000 & 1000 & 500 \\
\hline 9 & 200 & 500 & 500 & 200 & 500 & 500 & 200 & 500 & 500 & 200 & 500 & 500 & 200 & 500 & 500 \\
\hline 10 & & & & 0 & 300 & 0 & 0 & 300 & 0 & 0 & 30 & 0 & 0 & 30 & 0 \\
\hline 11 & & & & & & & 30 & 100 & 200 & 30 & 100 & 200 & 30 & 100 & 200 \\
\hline 12 & & & & & & & & & & 100 & 300 & 500 & 100 & 300 & 500 \\
\hline 13 & & & & & & & & & & & & & 100 & 50 & 500 \\
\hline
\end{tabular}


Table 6: Service duration time \& Location information.

\begin{tabular}{cccc}
\hline \multirow{2}{*}{ Node } & $\begin{array}{c}\text { Service Duration } \\
\text { Time (min) }\end{array}$ & \multicolumn{2}{c}{ Location } \\
\cline { 3 - 4 } & 1 & $\mathrm{X}$ & $\mathrm{Y}$ \\
\hline 1 & 15 & 975.690 & 0 \\
2 & 20 & 457.692 & 411.985 \\
3 & 15 & 336.499 & 148.378 \\
4 & 25 & 867.212 & 241.269 \\
5 & 25 & 919.882 & 547.194 \\
6 & 10 & 766.775 & 360.531 \\
7 & 15 & 376.221 & 264.250 \\
8 & 25 & 998.429 & 979.084 \\
9 & 15 & 574.582 & 240.938 \\
10 & 15 & 900.367 & 860.861 \\
11 & 35 & 678.493 & 560.583 \\
12 & 35 & 606.304 & 601.788 \\
13 & 5
\end{tabular}

For example, since the number of nodes for Test 1 is 10 , the service time and location information received from Table 6 are taken up to the part where the data of node 10 is present.

The model has reached the optimum results for Test 1 and Test 2 of the given experimental test sets. Summary information about the results of the experimental test sets is given in Table 7. The information about the assignments and their results for each experimental test set is given in Table 8 .
Table 7: Experimental test sets results.

\begin{tabular}{ccccc}
\hline & $\begin{array}{c}\text { Number } \\
\text { of Node }\end{array}$ & $\begin{array}{c}\text { Total Route } \\
\text { Distance } \\
(\mathrm{km})\end{array}$ & $\begin{array}{c}\text { Total } \\
\text { Service } \\
\text { Duration } \\
(\mathrm{min})\end{array}$ & $\begin{array}{c}\text { Model } \\
\text { Time } \\
(\mathrm{sec})\end{array}$ \\
\hline Base Test & 9 & 535.691 & 152 & 23.714 \\
\hline Test 1 & 10 & 535.897 & 167 & 63.81 \\
Test 2 & 11 & 535.580 & 197 & 1055.78 \\
Test 3 & 12 & $540.798^{*}$ & $232^{*}$ & $3000.03 *$ \\
Test 4 & 13 & $559.371^{*}$ & $285^{*}$ & $2999.78^{*}$ \\
\hline
\end{tabular}

* The solution is not optimal.

The algorithm has reached the optimum result which is $535.897 \mathrm{~km}$ for Test 1 , in 63.81 seconds. When the algorithm was run for experiment Test 2 , the optimal solution results in a route length of $535.58 \mathrm{~km}$ in 1055.78 seconds. Tanks 2 and 3 are used by the model for Test $1 \&$ Test 2 . The values given in the Table 7 and Table 8 are the closest solution that the algorithm can find during the specified algorithm time.

\section{Sensitivity analysis}

\subsection{Supply increase analysis}

This analysis was performed to observe the solutions that the model would create with the change of milk supply. Data test sets are given in

Table 9.

Table 8: Experimental test set detailed solutions.

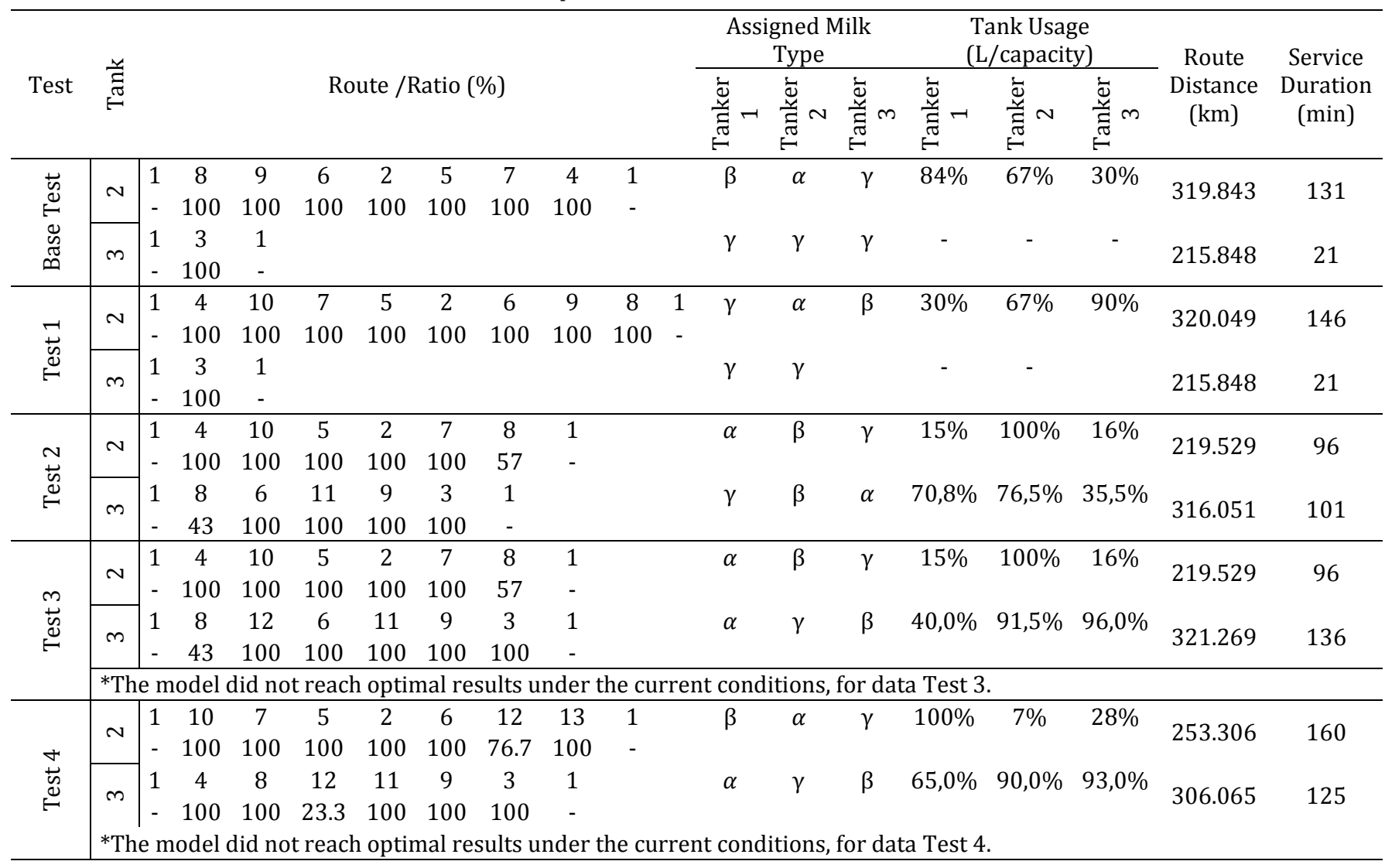


Table 9: Supply increase analysis data test set.

\begin{tabular}{|c|c|c|c|c|c|c|c|c|c|c|c|c|}
\hline \multirow{3}{*}{ Nodes } & \multicolumn{3}{|c|}{ Base Test } & \multicolumn{3}{|c|}{ Test 5} & \multicolumn{3}{|c|}{ Test 6} & \multicolumn{3}{|c|}{ Test 7} \\
\hline & \multicolumn{3}{|c|}{ Milk Production (L) } & \multicolumn{3}{|c|}{ Milk Production (L) } & \multicolumn{3}{|c|}{ Milk Production (L) } & \multicolumn{3}{|c|}{ Milk Production (L) } \\
\hline & $\alpha$ & $\mathrm{b}$ & $\gamma$ & $\alpha$ & $\mathrm{b}$ & $\gamma$ & $\alpha$ & $\mathrm{b}$ & $\gamma$ & $\alpha$ & $\mathrm{b}$ & $\gamma$ \\
\hline 1 & 0 & 0 & 0 & 0 & 0 & 0 & 0 & 0 & 0 & 0 & 0 & 0 \\
\hline 2 & 2000 & 2000 & 0 & 2000 & 2000 & 0 & 2000 & 2000 & 0 & 2000 & 2000 & 0 \\
\hline 3 & 0 & 0 & 5500 & 0 & 0 & 5500 & 0 & 0 & 5500 & 0 & 100 & 5500 \\
\hline 4 & 45 & 200 & 0 & 45 & 200 & 0 & 45 & 200 & 0 & 100 & 200 & 0 \\
\hline 5 & 35 & 0 & 0 & 35 & 0 & 0 & 3500 & 1000 & 0 & 3500 & 1000 & 0 \\
\hline 6 & 50 & 500 & 0 & 50 & 500 & 0 & 50 & 500 & 0 & 100 & 500 & 0 \\
\hline 7 & 0 & 0 & 500 & 0 & 0 & 500 & 0 & 500 & 500 & 0 & 500 & 500 \\
\hline 8 & 1000 & 1000 & 500 & 3000 & 3000 & 3000 & 2000 & 2000 & 2500 & 3000 & 3000 & 3000 \\
\hline 9 & 200 & 500 & 500 & 200 & 500 & 500 & 200 & 500 & 500 & 200 & 500 & 500 \\
\hline
\end{tabular}

In the data test sets used in this analysis, no parameters were changed except the milk type and milk amount produced by the producers. All parameters except milk type and quantity were taken from the base test given previously.

There is a difference between test 5 and the base test: Milk production of the eighth producer has been increased; production capacity for this producer is increased to 3000 liters for each type of milk. Therefore, in total 6500 liters are added to total milk production capacity. Thus, total supply / total capacity ratio is increased from $42.7 \%$ to $61.8 \%$ in test 5 compare to base test. In the data test 2 , the ratio of total milk amount to total capacity is increased to $69 \%$ and in the data test 3 , this ratio is increased to $\% 77$.

Summary about the results of the supply increase analysis experiments is given in Table 10. When the ratio of the total amount of milk production to total tank capacity is $77 \%$, the optimum solution cannot be obtained. The detailed solution of the supply increase analysis experiment test sets is given in

Table 11.

Table 10: Supply increase analysis results.

\begin{tabular}{lcccc}
\hline & $\begin{array}{c}\text { Total Supply / } \\
\text { Total capacity }\end{array}$ & $\begin{array}{c}\text { Route } \\
\text { Distance } \\
(\mathrm{km})\end{array}$ & $\begin{array}{c}\text { Service } \\
\text { Duration } \\
(\mathrm{min})\end{array}$ & $\begin{array}{c}\text { Model } \\
\text { Time } \\
(\mathrm{sec})\end{array}$ \\
\hline Base Test & $42.70 \%$ & 535.691 & 152 & 23.714 \\
\hline Data Test 5 & $61.90 \%$ & 627.643 & 168 & 52.769 \\
Data Test 6 & $69.10 \%$ & 746.402 & 178 & 27.432 \\
Data Test 7 & $77.10 \%$ & - & - & 0.64 \\
\hline
\end{tabular}

Table 11: Supply increase analysis detailed solutions.

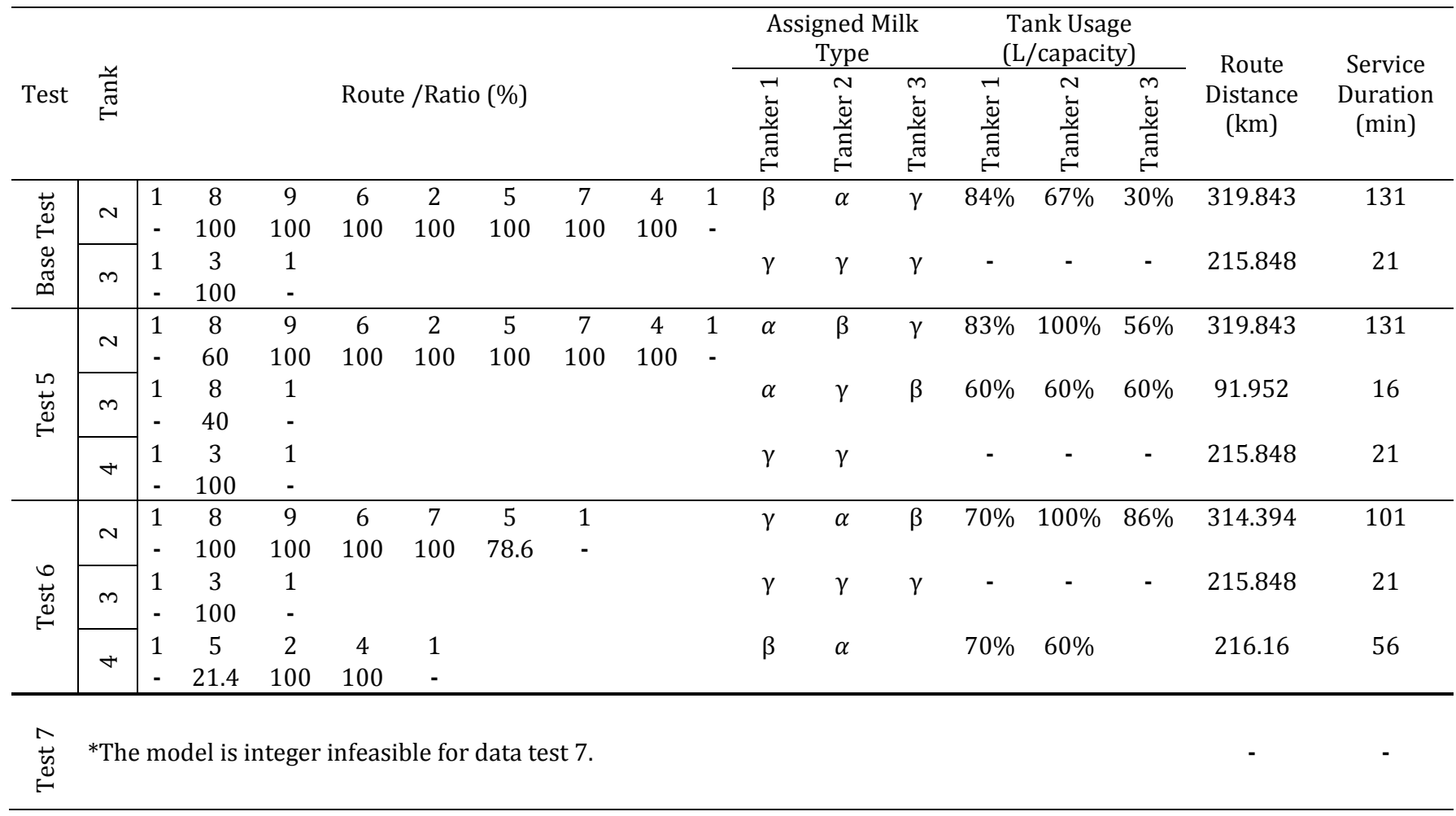




\subsection{Time limit decrease analysis}

One of the most important criteria for the preservation of milk quality is the total time spent on the road. For this reason, this model takes time limit constraint into account. In real life, the time limit for transportation of milk varies depending on geographical conditions, seasons and legal regulations.

In this analysis, the time limit, which was 3000 minutes in the basic data test, was further reduced in each test and reduced to 300 minutes in test 12 . Summary information about the results of the time limit analysis experiments is given in Table 12 .

Table 12: Time limit analysis results.

\begin{tabular}{ccccc}
\hline & $\begin{array}{c}\text { Time } \\
\text { Limit } \\
(\mathrm{min})\end{array}$ & $\begin{array}{c}\text { Route Distance } \\
(\mathrm{km})\end{array}$ & $\begin{array}{c}\text { Service } \\
\text { Duration } \\
(\mathrm{min})\end{array}$ & $\begin{array}{c}\text { Model } \\
\text { Time } \\
(\mathrm{sec})\end{array}$ \\
\hline Base Test & 3000 & 535.691 & 152 & 23.714 \\
\hline Test 8 & 2000 & 535.691 & 152 & 11.505 \\
Test 9 & 1000 & 535.691 & 152 & 12.117 \\
Test 10 & 500 & 535.691 & 152 & 18.197 \\
Test 11 & 400 & 610.819 & 172 & 19.803 \\
Test 12 & 300 & - & - & 19.442 \\
\hline
\end{tabular}

In the time limit analysis, we examined the solutions that the model can reach by reducing the time limit parameter in the model. In this analysis, no parameters except the total duration time limit parameter were changed. Detailed results of the analysis are given in

Table 13 .

Optimum solutions can be obtained for all data sets except the data set 12 . The model could not produce an optimum solution for the data test 12 where the time limit was 150 minutes, on the other hand, this time limit is not applicable. Given the reallife conditions, it is not viable for the nature of the milk collection problem to aim to collect different types of raw milk from a different location in as short a time as 150 minutes.

\subsection{Tank number increase analysis}

The base data test contains four different types of tanks in the model. The purpose of this analysis is to observe the performance of the model in increasing the number of tanks. The generated data test sets are given on

Table 14. In this analysis, no parameters were changed except the number of tanks and the capacities of newly added tanks.

In the data test 9 , the number of tanks has been increased to five. In each data test, the number of tanks was increased by one. When the number of the tanks has reached to seven, the analysis related to the increase in the number of tanks have been terminated.

Table 13: Time limit analysis detailed solutions.

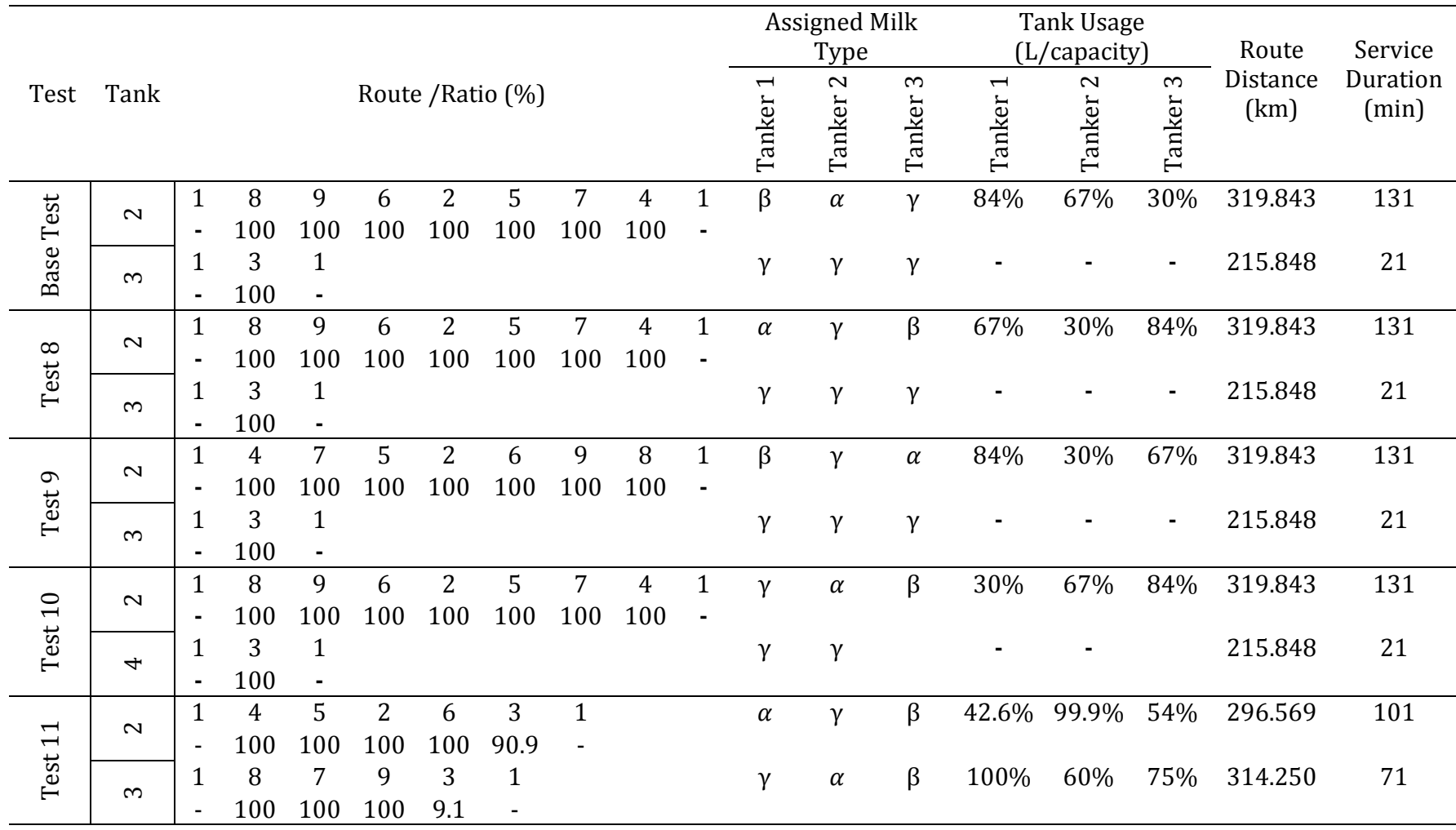

\footnotetext{
$\stackrel{\text { ㄱ }}{\vec{y}}$ The model is integer infeasible for data test 12
} 
Table 14: Tank increase analysis experimental test sets.

\begin{tabular}{|c|c|c|c|c|c|c|c|c|c|c|c|c|}
\hline \multirow[b]{3}{*}{ Tanks } & \multirow{2}{*}{\multicolumn{3}{|c|}{$\begin{array}{c}\text { Base Data Test } \\
\text { Capacity (L) }\end{array}$}} & \multicolumn{3}{|c|}{ Data Test 13} & \multicolumn{3}{|c|}{ Data Test 14} & \multicolumn{3}{|c|}{ Data Test 15} \\
\hline & & & & & pacity & & & pacity & & & pacity & \\
\hline & 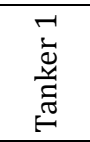 & 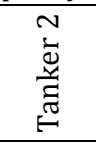 & 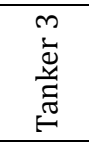 & 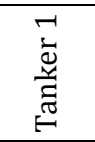 & 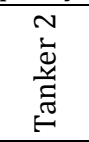 & 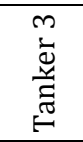 & 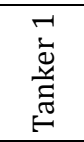 & 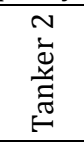 & 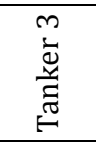 & 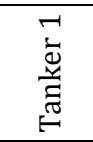 & 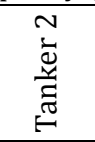 & 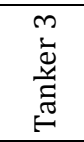 \\
\hline 1 & 5000 & & & 5000 & & & 5000 & & & 5000 & & \\
\hline 2 & 5000 & 5000 & 5000 & 5000 & 5000 & 5000 & 5000 & 5000 & 5000 & 5000 & 5000 & 5000 \\
\hline 3 & 2000 & 2000 & 2000 & 2000 & 2000 & 2000 & 2000 & 2000 & 2000 & 2000 & 2000 & 2000 \\
\hline 4 & 4000 & 4000 & & 4000 & 4000 & & 4000 & 4000 & & 4000 & 4000 & \\
\hline 5 & & & & 5000 & 5000 & 5000 & 5000 & 5000 & 5000 & 5000 & 5000 & 5000 \\
\hline 6 & & & & & & & 2000 & 2000 & 2000 & 2000 & 2000 & 2000 \\
\hline 7 & & & & & & & & & & 4000 & 4000 & \\
\hline
\end{tabular}

Data set results obtained from the tank increase analyzes are given in Table 15. Detailed results of the analysis are given in Table 16.

Table 15: Tank increase analysis results.

\begin{tabular}{ccccc}
\hline & $\begin{array}{c}\text { Number of } \\
\text { Tanks }\end{array}$ & $\begin{array}{c}\text { Route } \\
\text { Distance } \\
(\mathrm{km})\end{array}$ & $\begin{array}{c}\text { Service } \\
\text { Duration } \\
(\mathrm{min})\end{array}$ & $\begin{array}{c}\text { Model } \\
\text { Time }(\mathrm{sec})\end{array}$ \\
\hline Base Test & 4 & 535.691 & 152 & 23,714 \\
\hline Test 13 & 5 & 535.691 & 152 & 80.342 \\
Test 14 & 6 & 535.691 & 152 & 312.851 \\
Test 15 & 7 & 535.691 & 152 & 219.138 \\
\hline
\end{tabular}

In this analysis, no significant effect of the change in the number of vehicles in the model has been observed. The reason for this consequence is that the demand was unchangeable and only the increase in the number of vehicles has been observed.

\subsection{ANOVA Analysis}

In order to further analyze the results, a two-factor analysis of variance (ANOVA) has been conducted for each of the three analysis (Subsections 5.1, 5.2 and 5.3) which are supply increase, time limit decrease, and tank number increase. In order to make a fair comparison, total produced milk amount and total tank capacity have been taken consideration in ANOVA analyses.

Figure 2 depicts the results of the route distance to these three parameters interaction. Note that when the mathematical model could not find a solution (test 7 and 12), results for these sets are not considered in ANOVA analysis.

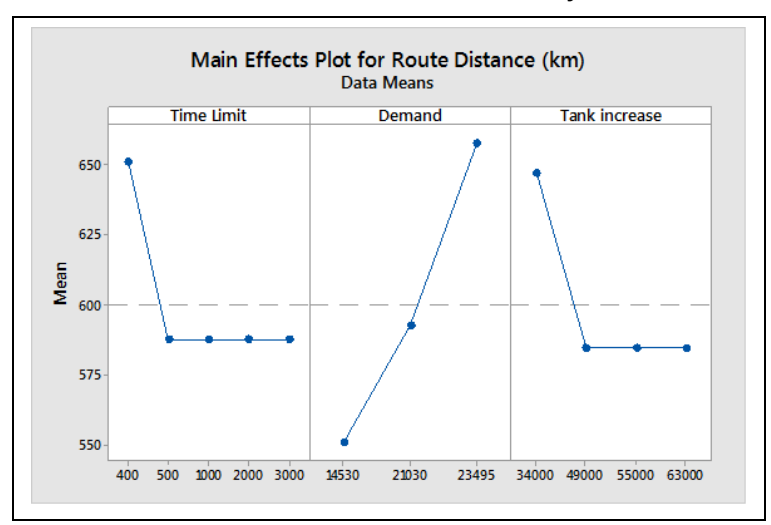

Figure 2: Parameter effects on the route distance.
The time limit decrease does not affect the route distance until it is equal to $400 \mathrm{~min}$. Supply increase has an influence on route distance. When the total supply is set to 23.495-liter, total route distance is set off more than $650 \mathrm{~km}$. While the total tank capacity is set to 49.000 , the route distance is reduced. After this decrease, while the total capacity increasing, the route distance stays the same.

Figure 3 indicates that when the total milk supply increased and the time limit decreased, the total route distance is increased. While the total tank capacity increases and the time limit is reduced, a reduction in the total route distance value is observed at the point where the total capacity reaches 49.000 liters, but the total route distance is stable for other comparisons. While the total milk supply and the total tank capacity are increasing, a reduction in the total route distance is observed at the same point which is where the total tank capacity is equal to 49.000 liters. After this decline, the total route distance remains constant.

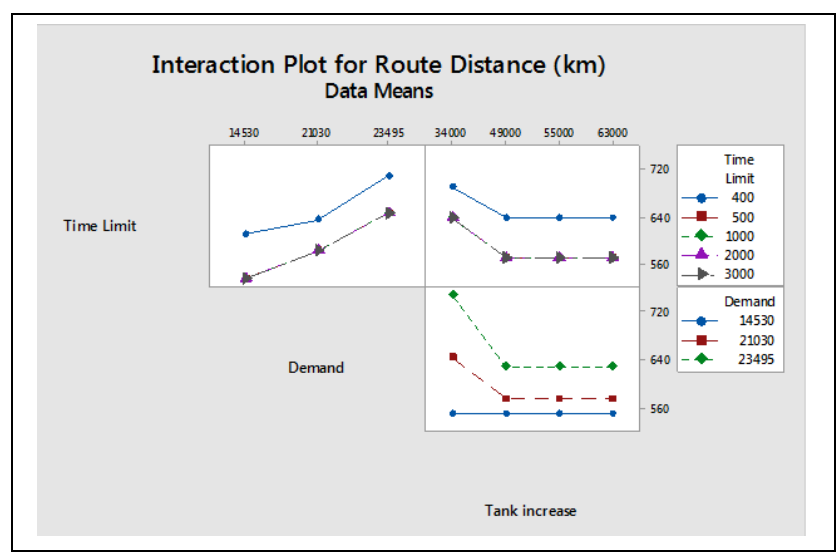

Figure 3: Interaction of parameters in terms of route distance.

\section{Conclusion}

In this study, milk collection problem is considered as an integrated model for the first time in the literature. We presented an integrated mathematical model which include known and new inequalities for the Milk Collection Problem.

A hypothetical case study test model based on real-life data which has 8 farm/collection center, 1 milk processing center and 3 milk types have been solved by using CPLEX solver. 
Table 16: Tanks increase analysis detailed solutions.

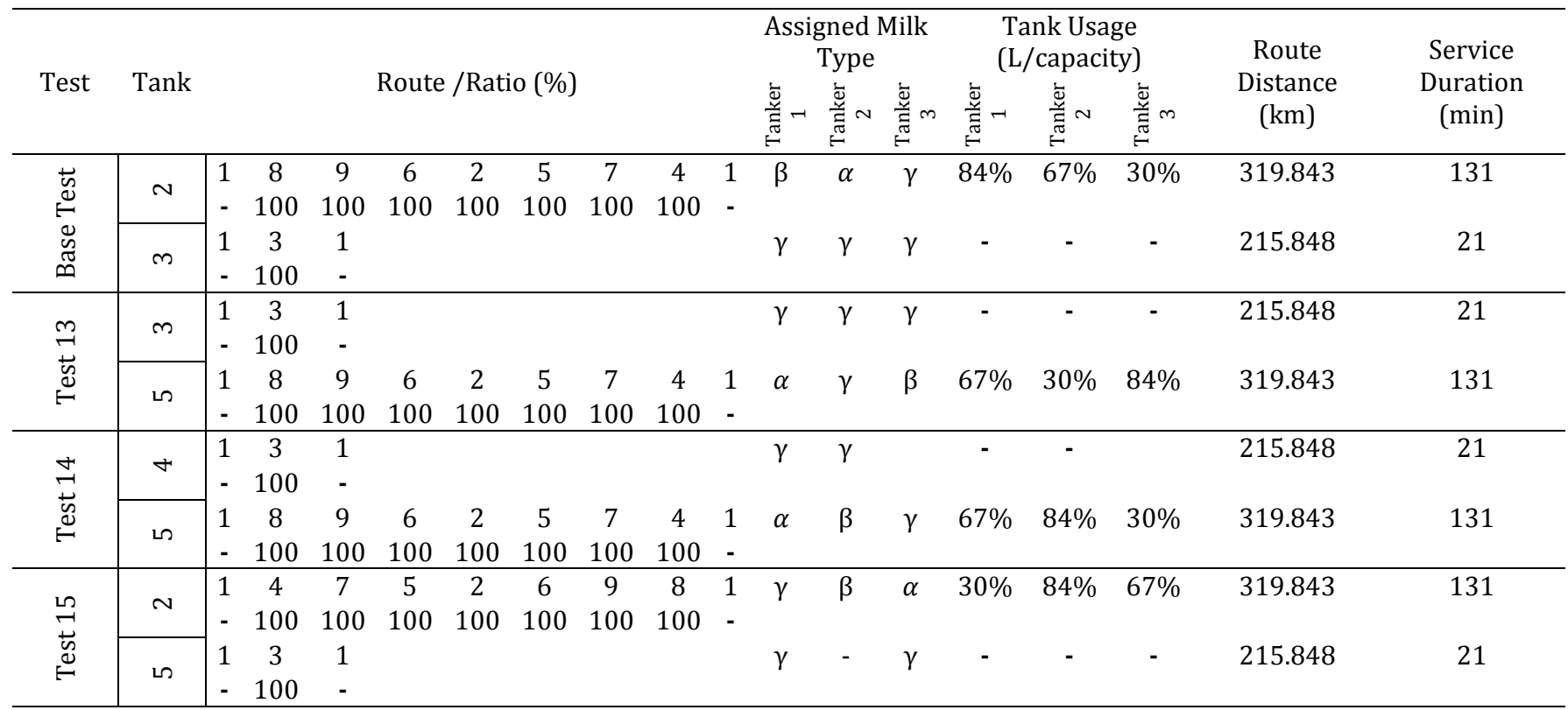

After validation of the results, a number of sensitivity analyze have been conducted in order to provide more help to the decision makers of the industry. Contrary to the popular belief in the industry, the model results show that logistics performance of the collection network can be maintained even without mixing different type of raw milks. The proposed model only able to optimally solve a tiny network if the possible size of the real collection network is considered. A typical milk collection problem can contain 50-300 service points in a day. Therefore, as a future research direction, efficient heuristic methods in vehicle routing problems such as large neighborhood search, variable neighborhood search or ant colony optimization should be adapted to milk collection problem in order to solve large problem instances. Additionally, vehicle specific constrains such as allowed time windows in farms and farm/vehicle compatibility might be added to developed mathematical model.

\section{Acknowledgment}

This work supported by the Scientific and Technological Research Council of Turkey (TÜBİTAK) under 217M578 project and Pamukkale University department of Scientific Research Projects (PAUBAP) under 2019FEBE024 project . This support is gratefully acknowledged.

\section{References}

[1] Prodhon C, Prins C. "A survey of recent research on location-routing problems". European Journal of Operational Research, 238(1), 1-17, 2014.

[2] Lahyani R, Khemakhem M, Semet F. "Rich vehicle routing problems: From a taxonomy to a definition", European Journal of Operational Research, 241(1), 1-14, 2015.

[3] Cuda R, Guastaroba G, Speranza MG. "A survey on twoechelon routing problems". Computers \& Operations Research, 55(0), 185-199, 2015.

[4] Vásquez RR, Valencia MC. "Model of routing for raw milk collection using genetic algorithms". Sistemas \& Telemática, 12(31), 77-87, 2014.
[5] Lahrichi N, Gabriel Crainic T, Gendreau M, Rei W, Rousseau LM. "Strategic analysis of the dairy transportation problem". Journal of Operational Research Society, 66(1), 44-56, 2015.

[6] Masson R, Lahrichi N, Rousseau LM. "A two-stage solution method for the annual dairy transportation problem". European Journal of Operational Research, 251(1), 36-43, 2016.

[7] Hoff A, Løkketangen A. "A tabu search approach for milk collection in western Norway using trucks and trailers". TRISTAN VI: Sixth Triennial Symposium Transportation Analysis, Phuket Island, Thailand, 10-15 June 2007.

[8] Pasha U, Hoff A, Løkketangen A. "A Hybrid Approach for Milk Collection Using Trucks and Trailers". Annals of Management Science, 3(1), 85, 2014.

[9] Amiama C, Pereira JM, Carpente L, Salgado J. "Spatial decision support system for the route management for milk collection from dairy farms". Transportation Letters, 7(5), 279-288, 2015.

[10] Chokanat P, Pitakaso R, Sethanan K. "Methodology to Solve a Special Case of the Vehicle Routing Problem: A Case Study in the Raw Milk Transportation System". AgriEngineering, 1(1), 75-93, 2019.

[11] Montero E, Canales D, Paredes-Belmar G, Soto R. "A Prize Collecting problem applied to a Real Milk Collection problem in Chile". IEEE Congress on Evolutionary Computation (CEC), Wellington, New Zealand, 10-13 June 2019.

[12] Polat 0, Topaloğlu D. "Milk Collection Network Design İn A Fuzzy Environment”. Economy\&Business, 13, 376-384, 2019.

[13] Caramia M, Guerriero F. "A Milk Collection Problem with Incompatibility Constraints". Interfaces, 40(2), 130-143, 2010.

[14] Laporte G, Nobert Y. "Exact algorithms for the vehicle routing problem", North-Holland Mathematics Studies $132,147-184,1987$. 
[15] Polat O, Kalaycı CB, Kulak O, Günther HO. "A perturbation based variable neighborhood search heuristic for solving the Vehicle Routing Problem with Simultaneous Pickup and Delivery with Time Limit". European Journal of Operational Research, 242(2), 369-382, 2015.
[16] Polat O. "A Parallel Variable Neighborhood Search for the Vehicle Routing Problem with Divisible Deliveries and Pickups". Computers \& Operations Research, 85, 71-86, 2017. 